\title{
Exchange rate regulation in economic unions: The case of Euroasian Economic Union
}

\author{
M. A. Voskanyan, A. H. Galstyan \\ Russian-Armenian (Slavonic) University, \\ 123, Hovsep Emin st., Yerevan, 0051, Armenia
}

For citation: Voskanyan M.A., Galstyan A.H. (2021) Exchange rate regulation in economic unions: The case of Euroasian Economic Union. St Petersburg University Journal of Economic Studies, vol.37, iss. 1, pp. 140-165. https://doi.org/10.21638/spbu05.2021.106

This article explores currency regulation in the EAEU countries for the harmonization of currency policies in the context of economic integration. The object of the study is currency regulation in countries of Eurasian integration. The main hypothesis is that EAEU member countries are not ready for currency integration, due to the presence of many macroeconomic distortions in their economies. The authors assess the possibility of creating a monetary union by analyzing and evaluating key criteria for currency integration as known in the scholarly literature. For this goal, the authors conducted a literature review of the key prerequisites for currency integration, including the experience in the countries of the Eurozone. Then the authors analyze currency regulation in EAEU countries for meeting key criteria for currency integration. At this stage, the authors evaluate key factors of currency integration by EAEU member countries. The theoretical and methodological basis of the study was classic and modern approaches in the field of monetary and currency regulation-in particular, the research of modern analysts of the International Monetary Fund, the largest Central Banks of the world, and well-known experts of the field. The research results showed the inexpediency of creating a currency union within the Euroasian economic space at this stage.

Keywords: economic integration, monetary union, currency regulation, EAEU.

\section{Introduction}

The experience of European integration shows that after the creation of an economic union, member countries gradually go through certain stages, from simple forms of inte-

(C) St. Petersburg State University, 2021 
gration to complex ones, that is, from customs union to economic, monetary, and political unions. According to the theory of economic integration, the result of economic integration is monetary integration, following the example of the European Union. However, in practice, this is not often the case.

Thus, after achieving some success in establishing an economic union, the union is faced with the problem of a unified monetary regulation. The lack of harmonization of monetary and currency regulation can lead to economic disruptions. These disruptions can occur in the form of currency crises and mutual trade issues. Moreover, exchange rate fluctuations can occur in member countries. P. Aghion, P. Bachetta, R. Ranciere and K. Rogoff [Aghion et al., 2006] have shown that exchange rate volatility harms economic growth, especially in low-income countries. G. Schnabl [Schnabl, 2009] also came to this conclusion in his work. This shows the importance of the issue of monetary regulation coordination within the economic union.

On the other hand, the currency union has a significant impact on foreign trade. Using econometric models, A. Rose [Rose, 2008] has shown that the European Union has raised mutual trade within the Eurozone by between 8 and $23 \%$. Thus, the analysis of the prospects for harmonization of exchange rate regulation within the EAEU is a relevant subject for all member states and the Union as a whole. Over time EAEU member states will also seek to strengthen integration into the Eurasian space, including through currency integration.

In the current article the authors explore the currency regulation in the EAEU countries for the harmonization of currency policies in the context of economic integration. The object of the study is currency regulation in countries of Eurasian integration. The main hypothesis is that EAEU member countries are not ready for currency integration, due to the presence of many macroeconomic distortions in their economies. The structure of the article includes the literature review, analysis and assessment of currency integration factors within EAEU and concluding remarks.

\section{Literature review}

The theory of the optimal currency zone is the theoretical basis of the currency union [Mundell, 1961; McKinnon, 1963; Kenen, 1969]. The traditional approach for creating an optimal currency zone is based on a combination of pros and cons of floating and fixed exchange rate policies. The main criteria for the effectiveness of creating a currency zone are:

- production factors mobility;

- economic openness;

- economic diversification;

- degree of fluctuation in inflation rates;

- indicators of economic integration;

- fiscal integration.

We discuss each of these criteria.

R.Mundell [Mundell, 1961] observes the regional mobility of production factors (primarily the labor force) as a substitute for price and wage flexibility, which, in his opinion, is limited in the short term. At the same time, he was against the full mobility of production factors, as this could cause serious issues with balances of payments. However, 
Mundell's model is characterized by numerous controversial factors that have been identified by other authors. For example, J. Fleming [Fleming, 1971] emphasizes the positive implications of having similar inflation levels and applying long-term fixed exchange rate regimes. At the same time, he also gives importance to the dynamics of other macroeconomic indicators, such as investment flows and their impact on economic growth, various internal and external shocks within the monetary union, and so on. Another factor that Mundell did not consider in his model is the impact of additional negative shocks, such as negative net migration. Thus, G. Bertolla [Bertolla, 1989] studies the migration of population from one region of the currency zone to another, taking into account the costs of relocation and further adaptation to the new country. He concludes that such migration is inevitable in the case of large income differentials between different regions of the optimal currency zone. On the other hand, W. Corden [Corden, 1973] argues about the full mobility of labor force within the region, denying the risks associated with migration, as according to his calculations the costs could be too high.

Nevertheless, as the experience of the European Union has shown, such a trend bears significant negative consequences for both low- and high-income countries. Further, if the outflow of human capital from low-income countries meant a loss of economic potential from the perspective of the host countries, the excess inflow of human capital leads to rising unemployment and some demographic issues. Figure 1 demonstrates that in countries with a lower income level, there is a significant CPI, and on the contrary, net migration in leading economies is characterized by significant positive values.

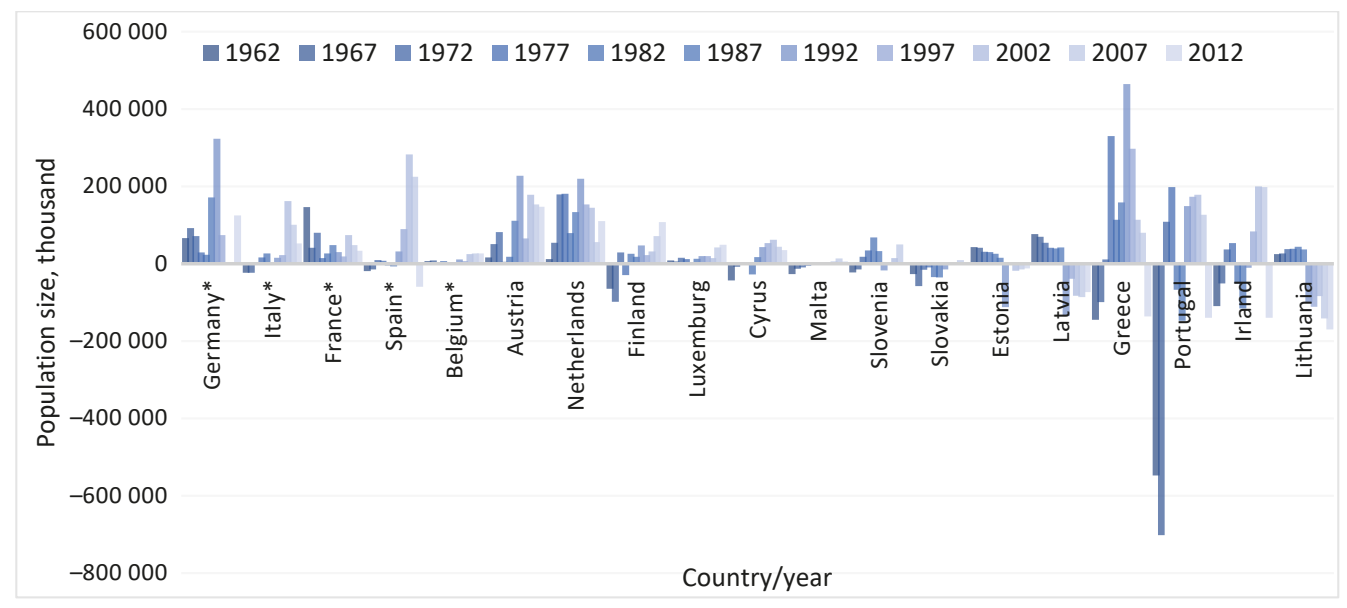

Fig. 1. Net migration in the Eurozone Countries, 1962-2017, every 5 years

Based on: The World Bank Database. URL: https://data.worldbank.org (accessed: 12.11.2019).

R. McKinnon [McKinnon, 1963] notes that economic openness is more important than the mobility of production factors. At the same time, small countries are quite open, and large economies are more integrated through internal trade links and, therefore, more closed to other regions. The exchange rate mechanism under a flexible currency regime will not work effectively in small open economies, as inflationary processes, which leave real wages unchanged, cannot be avoided. Consequently, many small open economies are candidates for the creation of a currency zone with other economies. 
P. Krugman [Krugman, 1991] shows that strong trade integration between countries may conflict with the precondition for low asymmetric shocks. Trade integration tends to bring regional specialization, which increases the risk of asymmetric shocks. For this reason, the mobility of factors is an unchanging condition of optimum currency areas.

J. Frankel and A. Rose [Frankel, Rose, 1998] showed that the intensity of the trade has a strong positive effect on the synchronization of the business cycle, ie the criteria for the optimal currency zone together are endogenous factors. If the monetary union reduces the transaction costs of the trade, thus increasing it, it can also reduce the disproportion of the business cycle.

At the same time, the geographical mobility of factors in the currency zone is necessary only if inter-branch mobility cannot take place within the region or for some reason is impossible. Also, the mobility of these factors may be more a result of the unification of the single currency, as such a policy may contribute to the interregional mobility of the workforce, if necessary in terms of macroeconomic regulation.

On the other hand, the higher the exchange rate of the national currencies of the member states, the more volatile prices will be in those countries, as open economies are subject to the demand and supply of foreign markets. McKinnon argues that the tightening of export prices could lead to a drop in import prices if strict measures are taken to stabilize the country's domestic prices, which will cause a decline in domestic demand and rising unemployment within the country. At the same time, the single currency will reduce transaction costs in the context of an open economy, as such countries are more involved in foreign economic activity, which in turn is a major factor in the formation of Gross Domestic Product (GDP).

However, we should mention that this criterion also has shortcomings. For example, it does not take into account the impact of price fluctuations on the exchange rate within the fixed exchange rate regime, especially in case of significant price fluctuations. Besides, R. McKinnon considers only a small open economy when the integration union can include both small and large economies. Therefore, the impact of the creation of a single currency zone for different types of economies will also be different. This is evidenced by the experience of the European Union.

On the other hand, P. De Grauwe [De Grauwe, 2003] questions the effectiveness of exchange rate adjustments, as they can be very costly for the economy and cause asymmetric shocks so that the cost of losing this instrument is lower than expected in the first generation of the optimal currency zone. theories. Unlike later authors, who also addressed this issue in their work, he considered the political union to be a necessary component of the monetary union (although not a precondition) [De Grauwe, 2006].

Unlike R. McKinnon [McKinnon, 1963], P. Kenen [Kenen, 1969] argues that economic differentiation is a much more important factor in creating an optimal currency zone than, for example, the mobility of production factors. Well-differentiated economies have fewer issues with overcoming asymmetric shocks, as they can be averaged, which allows taking advantage of a fixed exchange rate regime as long as inflationary pressures can ease compared to the economies to which they are attached.

It can be assumed that well-differentiated economies have similar production structures, and therefore have similar macroeconomic environments and real-time indicators, such as income per capita or productivity. Kenen supported the Bretton Woods system, 


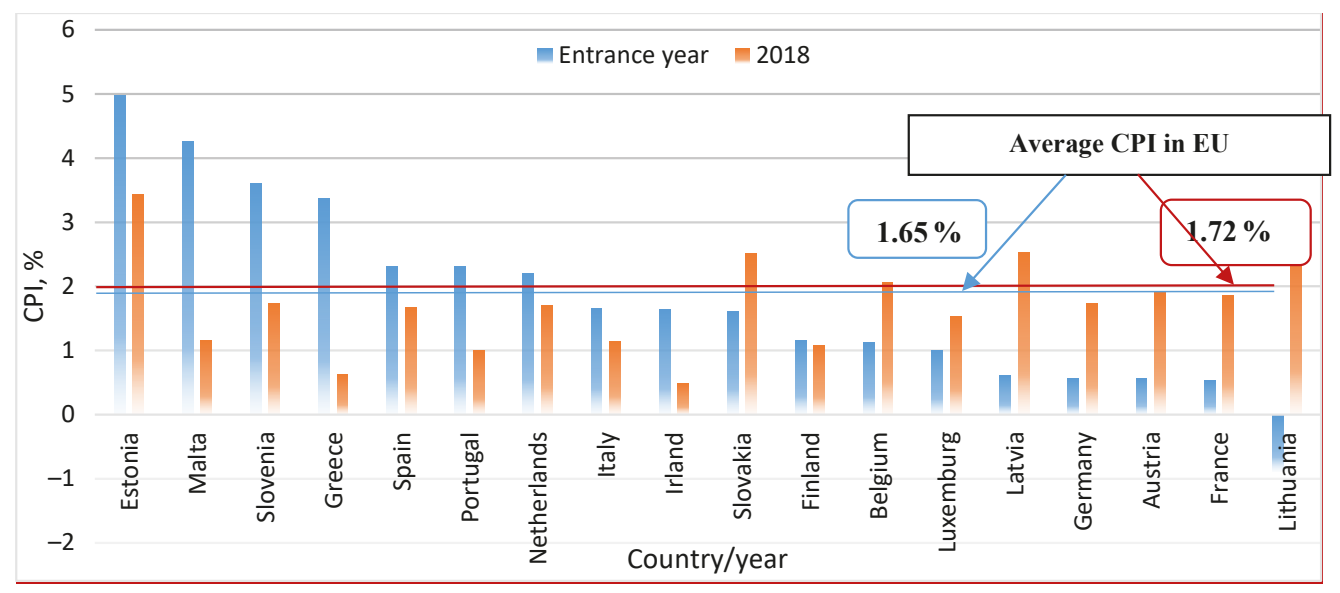

Fig. 2. CPI in EU countries

Based on: The World Bank Database. URL: https://data.worldbank.org (accessed: 12.11.2019).

and called for more flexible exchange rates, mainly in low-differentiated countries. The latter is more in need of currency exchange when overcoming external shocks.

In addition to the above, the volatility of inflation rates is a key criterion in the context of the currency zone. According to J. Fleming [Fleming, 1971], the agreed monetary policy can lead to a harmonization of price levels in the countries that will later be united in a single currency. This criterion was taken into account when developing the criteria for joining the Eurozone.

The need for this criterion lies primarily in the fact that a sharp difference in the price level in countries can lead to a difference in the equivalence of national currencies, which in turn can be offset by a floating exchange rate policy. Thus, for the efficient operation of the optimal currency zone, the similarity of inflation and floating exchange rate policy in the member states of the integration union is necessary.

However, this criterion is also characterized by certain shortcomings. In particular, as the experience of the European Union has shown, many countries are characterized by different price levels after joining the currency union (Fig. 2). At the same time, there was a lack of convergence of prices in the EU countries both at the time of joining the currency union and in 2018. In other words, this criterion, although included in the Maastricht Treaty, has largely been ignored.

Another disadvantage of price convergence is that, given the structural differences between the economies of the member states of the Union, the priority over price or unemployment can vary considerably. And this, in fact, from the very beginning makes it difficult for different economies to participate in the single currency zone.

Also, the similarity of price levels is taken to the leading country in the union, as in the case of the European Union, Germany. However, in this case, the entire monetary policy within the framework of the currency union is carried out towards the monetary policy of the leading country, thus not taking into account the peculiarities of the economies of other member states. In this sense, Greece is a clear example.

From the beginning, Mundell noted the need for the structural similarity of economies in the eurozone. According to him, this would reduce the risks of external shocks, 
as the presence of a single currency would harm all economies. That is why the structural similarity of economies should allow countries to pursue a common macroeconomic policy to offset the negative effects of external shocks. But on the other hand, it means the inefficiency of the floating exchange rate in such a situation. P. Krugmann and M. Obstfeld [Krugman, Obstfeld, 2003] emphasize that economic integration is a prerequisite for joining the currency zone, and includes trade integration, structural similarity, mobility of factors of production, and fiscal integration. Their position presupposes a relatively small optimal currency zone, which also requires at least certain elements of a political union.

Financial integration is also quite important. J. C. Ingram [Ingram, 1969] notes that economies with high levels of integration do not have to have a single currency regime in terms of financial systems. At the same time, in the face of low levels of financial integration, the difference in interest rates, in the long run, can lead to further reductions in the size of the financial system, and consequently capital outflows to more profitable markets.

Now let's consider fiscal policy, which is one of the most important macroeconomic tools of the state, aimed at balancing employment and unemployment. In this sense, an optimal currency zone is supposed to coordinate the fiscal policies of the participating countries. P. Kenen [Kenen, 1969] argues that the imperfect mobility of the workforce can be offset by the regional coordination of fiscal policy within the currency area. At the same time, the direction of fiscal regulation should coincide with the general direction of the monetary union. However, the author considers the currency union to be based on the Bretton Woods principle of currency attachment rather than as a single currency. However, experience shows that the existence of different fiscal policies in the context of a single currency may be an obstacle to the effectiveness of the union.

A least in the Eurozone, the single monetary policy has led to the loss of independence of countries regarding macroeconomic policies, which harmed countries such as Greece, Portugal, and others. The main reason for the issues in the eurozone was the focus of common monetary policy, first of all, on the stabilization of the monetary sector and then the macroeconomic sector, while the structural differences between the economies of the eurozone member states required different approaches to combating external shocks.

Contemporary authors note the so-called "proxy" criteria as additional criteria for the optimal currency zone. Thus, H. Fukuda [Fukuda, 2002] offers criteria based on various macroeconomic indicators of the economies of the member states, based on the calculated variability, correlation and covariance base. J. Frankel and A. Rose [Frankel, Rose, 1998] highlight the exogeneity of preconditions mentioned in other concepts. After the establishment of the currency zone, the mutual agreement of the trade rounds, the reduction of asymmetric shocks, the mobility of regional factors and regional exchange, and finally the increase of convergence take place, but the accuracy of these adjustments remains unknown. Here we are talking about relatively large optimal currency zones. Nothing is said about the role of political unity, fiscal federalism and so on.

R. Vaubel [Vaubel, 1976] talks about real exchange rate fluctuations, which should be taken as an indicator of the level of readiness of a country to enter the currency zone. Another article [Alesina, Barro, Tenreyro, 2002] pays attention to the indicator of shocks correlation. The presence of a high degree of correlation between external and internal shocks in the countries of the optimal currency zone means that the countries are subject to identical shocks and will subsequently pursue a similar macroeconomic policy aimed at stabilizing the economy. A low correlation will mean just the opposite. 
No less important are institutional and political standards, which were partially mentioned in the works of earlier authors.

Thus, the above-mentioned criteria take into account not all the peculiarities of currency zones, but rather separate private experiments. At the same time, most of the existing works don't reflect much the consequences for the economies from the entrance to the optimal currency zone. Several contemporary works are dedicated to the consequences of entering the optimal currency zone, both positive and negative.

Thus, using currency zone data before the creation of the Economic and Monetary Union (EMU), A. Rose [Rose, 2000] for the first time assessed the impact of the currency zone on the trade and concluded that it would lead to an excessive increase in the volume of mutual trade. A. Rose and T. Stanley [Rose, Stanley, 2005] later gave a quantitative assessment of this effect, concluding that currency zones increase mutual trade by $30 \%$.

A. Rose and Ch. Engel [Rose, Engel, 2002] looked at other macroeconomic aspects of the impact of currency zones before the creation of the EMU and found that countries in the currency area are more integrated than countries with their own currency but less integrated than different regions of a country. S. Edwards and I. Magendzo [Edwards, Magendzo, 2006] studied the inflation, growth, and volatility of countries in the currency area compared to other countries, and found that currency zones have lower levels of inflation and higher levels of production volatility than other countries.

P. R. Bergin and Ch.Y.Lin [Bergin, Lin, 2010] also looked at the impact of currency zones on mutual trade volumes. For macroeconomic and econometric analysis of this effect, they used the Dynamic stochastic general equilibrium (DSGE) model and found that the monetary union reduces irreversible or fixed but recurring trade costs, ie trade results are incompatible with the extensive marginal trade. These findings help determine what types of expenses are deducted when joining the currency union, which means that much of the benefits from the currency union depend on the expectations of traders concerning the assumption that the currency union will continue to exist.

The work of K. Aristotelous and S. Fountas [Aristotelous, Fountas, 2012] presents the impact of the EMU on foreign direct investments in 12 countries, where the euro was already accepted as a national currency. For their analysis, they used data from 22 Organisation for Economic Co-operation and Development (OECD) countries from 1973 to 2006. They concluded the following. First of all, the overall impact of the EMU on the inflow of foreign direct investments (FDI) to the Eurozone is positive and statistically significant. This result is stable for different evaluation methods and periods. Second, the results of the analysis suggest that the impact of the EMU on the inflow of FDI is different in different eurozone member states. In particular, they show that the impact of the EMU was positive and significant mainly in the countries, which are at the center of the currency union, and negative or mixed in the countries that are on its outskirts.

The work of A. Lipinska and L. Thadden [Lipinska, Thadden, 2012] examines the hypothesis of fiscal devaluation in the model of a monetary union characterized by national fiscal and supranational monetary policy. This analysis showed that as long as there is no financial integration between member states, the external effects will be as insignificant as the quantitative impact of the change in the tax structure on the closed economy.

Another important issue is the stability of the currency zones. P. Canofari, G. Marini, and G. Piersanti [Canofari, Marini, Piersanti, 2012] proposed a new method of assessing countries' vulnerability to crises for countries that use a pegged currency regulation 
regime (for example, currency unions, currency councils, and full dollarization) where traditional currency market pressure indices are not applicable.

Thus, the literature review showed that the majority of the authors attach great importance to the macroeconomic balance of the economies entering the currency zone. In this regard, in the next part of the work, we attempt to assess the opportunities for currency integration within the EAEU.

\section{Currency regulation within EAEU: Analysis and assessment of currency integration factors}

The creation of a common integration area aims to increase the economic potential of the union's member states. Over time EAEU member states will also seek to strengthen integration into the Eurasian space, including through currency integration.

As it is known, currency integration does not necessarily imply the formation of a single monetary union - it can also imply some other, simpler ways of integration. For example, we can talk about a joint payment system or an agreement about doing mutual trade payments in national currencies and several other alternatives.

On the other hand, the EAEU differs from other integration unions in that the relations between countries are rather focused on trade and economic relations of member states with Russia, and not on all the member states in general.

Within this study, we have done a statistical overview as well as calculated the indicators of convergence between the main economic characteristics of the EAEU member states. We used Dickey - Fuller's test to detect the presence of convergence, which allows time series to be tested for unit root. The null hypothesis is that if there is a unit root in time series, then there is no convergence. The time series used for the calculations were logarithmic on a natural basis, and for the Dickey - Fuller's test, we have used the bilateral differences between the indicators of the EAEU member states ${ }^{1}$.

We have accepted the non-occurrence of convergence (the existence of a unit root) as a null hypothesis, and the existence of convergence as an alternative. The hypothesis of the existence of a unit root can be presented as follows:

$$
H_{0}: x_{i, t} \equiv\left(Y_{i, t}-Y_{\star}, t\right)=I(1), \forall i=1,2, \ldots, N .
$$

Where $x_{i, t}$ - is the $Y$ indicator selected for the $i$ country compared to the other country, $N$ is the number of countries, $I(1)$ is a non-stationary process with a unit root [Cheung, Pascual, 2004].

The series were also checked for normal distribution.

As we have seen in the literature review, the level of development of the member states of the Union, both in terms of economic cycles and the convergence of income per capita, has high importance.

Considering these indicators for the EAEU member states, it can be noted that the economic cycles in these countries do not coincide (Fig. 3), as evidenced by the calculations of convergences for GDP growth rates. According to these calculations, at the level of $5 \%$ significance, we do not have sufficient grounds to accept the null hypothesis of the existence of convergence between the GDP levels of the EAEU countries.

\footnotetext{
${ }^{1}$ The calculations were done in Eviews 10 econometris package.
} 


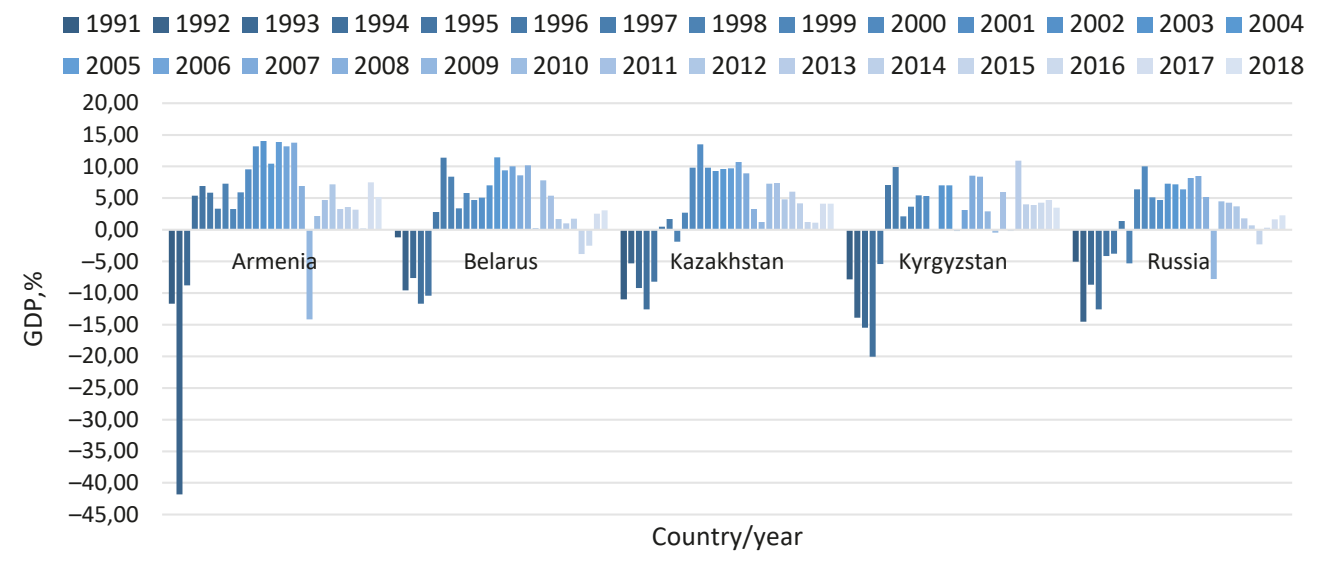

Fig. 3. GDP growth, annual, 1991-2018

Based on: The World Bank Database.URL: https://data.worldbank.org/ (accessed: 06.03.2020).

As we can see in Fig. 4, the income per capita is the highest in Russia and Kazakhstan, while the other three countries have incomparably low levels of income in comparison to Russia: Belarus almost twice, Armenia -3 times, Kyrgyzstan -9 times.

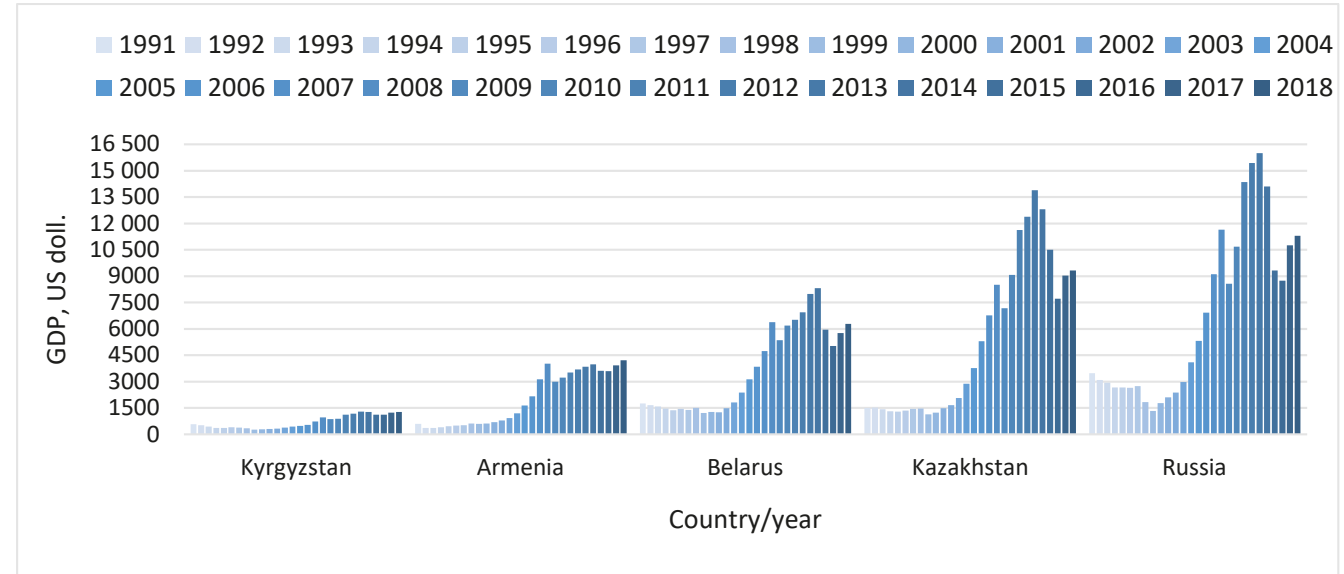

Fig. 4. GDP per capita, 1991-2018

Based on:The World Bank Database. URL: https://data.worldbank.org/ (accessed: 06.03.2020).

Thus, at least in terms of the level of economic cyclicality and income, countries may face the issue of disproportionate movement of resources within the monetary union.

\subsection{Mobility of production factors}

Given the difference in the levels of development of the economies of the EAEU member states, the mobility of factors of production can play a negative role in the creation of a monetary union between these countries, as evidenced by migration flows (Fig. 5). 


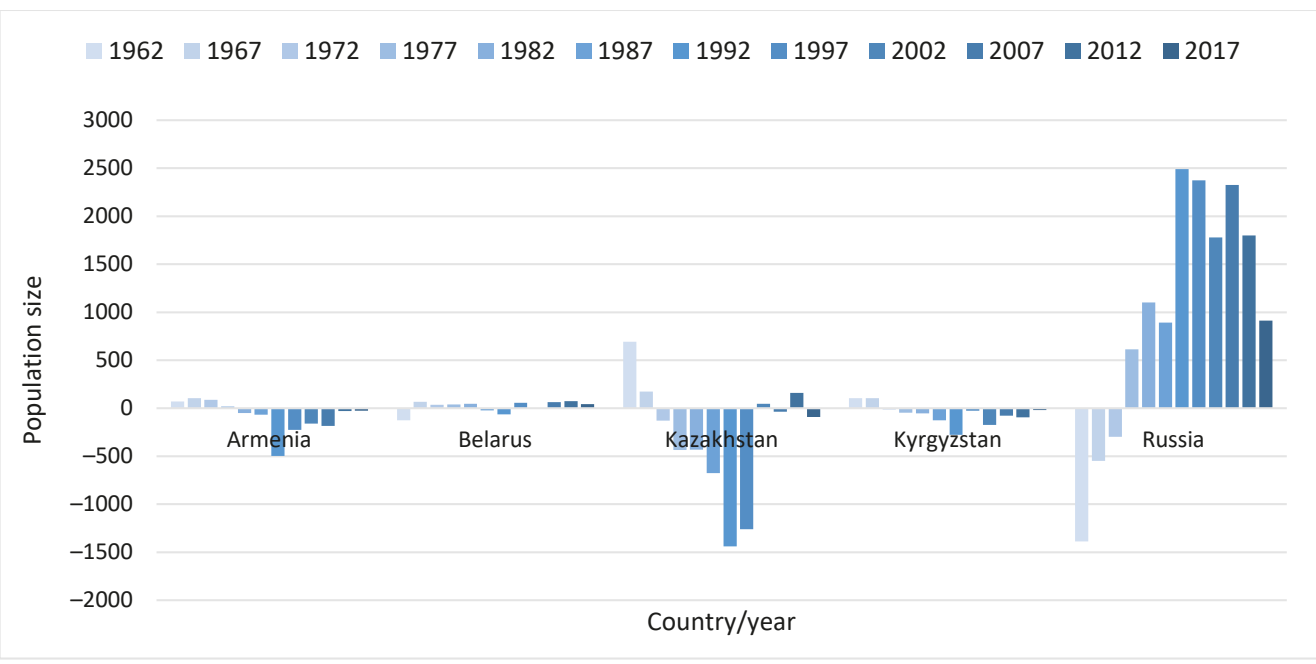

Fig. 5. Net migration, 1992-2017

Based on: The World Bank Database. URL: https://data.worldbank.org/(accessed: 06.03.2020).

As we can see in Fig. 5, during the years of independence in Armenia, as well as in Belarus, Kyrgyzstan, and especially in Kazakhstan, a large outflow of the population is observed, while in Russia the picture is the opposite. At the same time, it should be noted that according to the assessment made in 2000, after which no such assessment has been made yet, in Armenia 9\% of the qualified human capital migrated, which at least reduces Armenia's economic development potential in the future. Meanwhile, in other EAEU member states, this figure is quite low (Fig. 6).
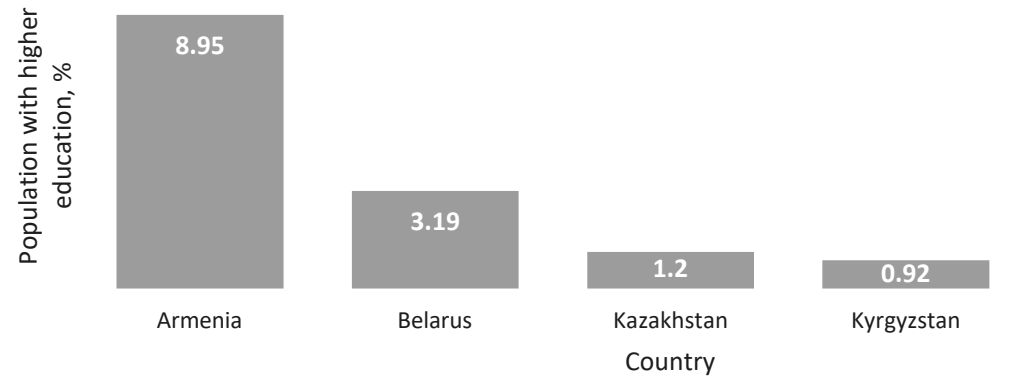

\subsection{8 \\ Russia}

Fig. 6. Emigration of people with higher education, 2000

Based on: The World Bank Database. URL: https://data.worldbank.org/(accessed: 06.03.2020).

Another factor of mobility is the movement of capital between countries. The movement of investments shows that the movement of capital from Russia to other EAEU member states is significantly higher than in the opposite direction (Fig. 7). 


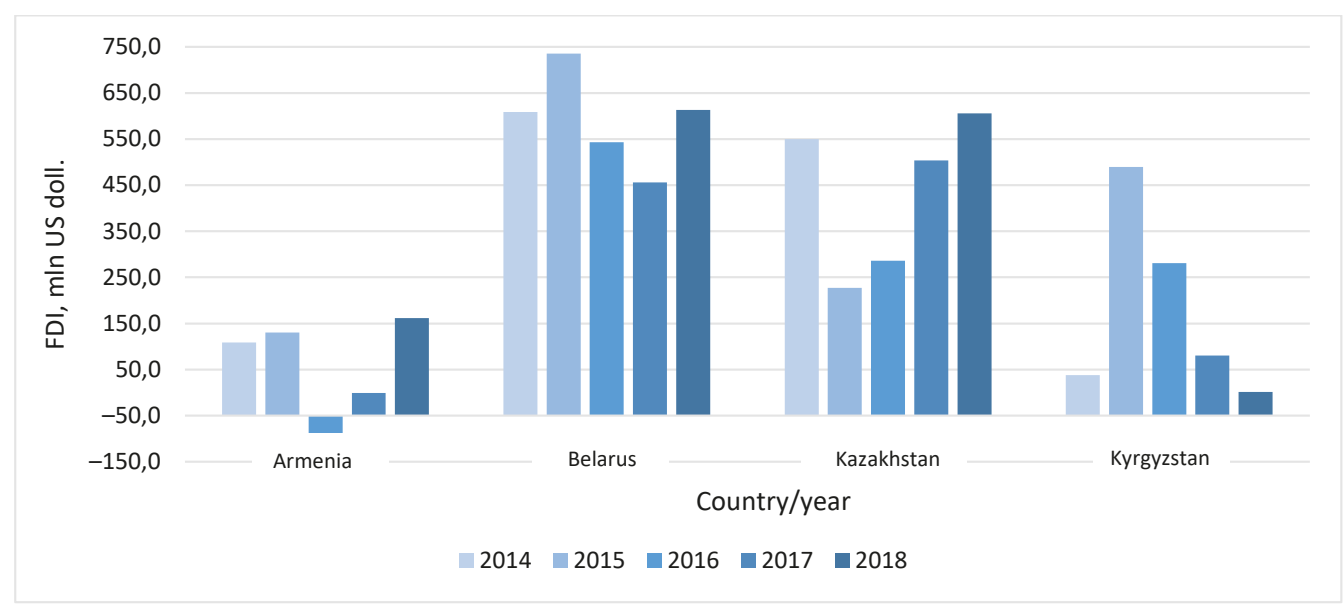

Fig. 7. The flow of foreign direct investment from Russia to the EAEU member states, 2014-2018

Based on: Euroasian Economic Commission Database. URL: http://www.eurasiancommission.org (accessed: 06.03.2020).

As we can see in Fig. 8, there is a slightly significant flow of foreign direct investment to Russia only from Kazakhstan, while the flow from other countries to Russia is very small.

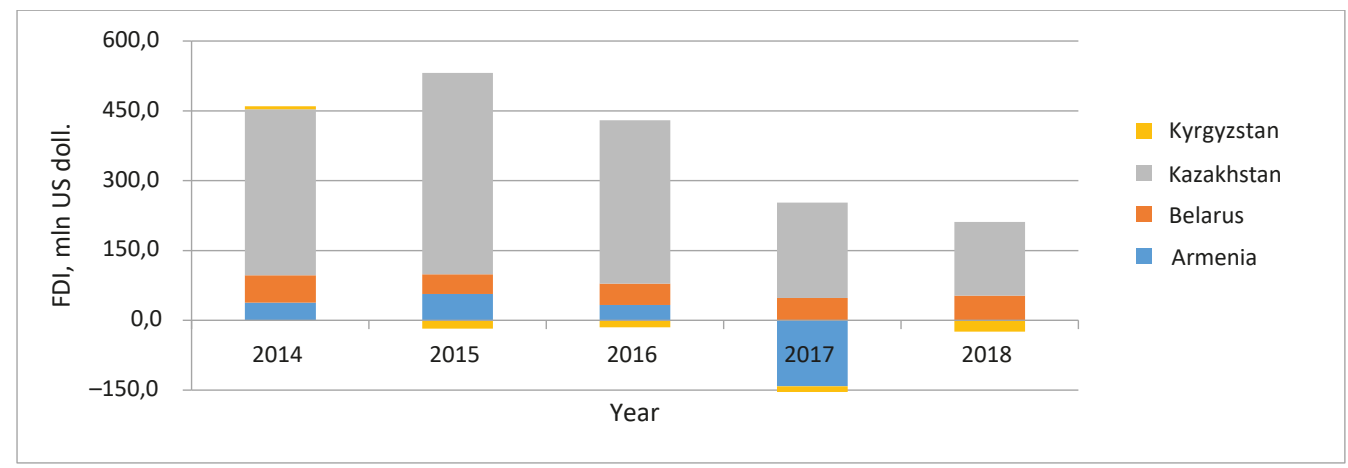

Fig. 8. The flow of foreign direct investment from the EAEU member states to Russia, mln US doll., 2014-2018

Based on: Euroasian Economic Commission Database.URL.http://www.eurasiancommission.org (accessed: 06.03.2020)

When we consider the inflow of foreign direct investment between other EAEU member states except Russia, it is obvious that in this case, the picture is even worse (Fig. 9).

As shown in Fig. 9, Armenia is separated from the other three countries in this respect, and the ties are more or less strong only between Kazakhstan and Kyrgyzstan. However, direct investment flows between the four countries do not exceed 25 million USD annually, which is a very low figure. 


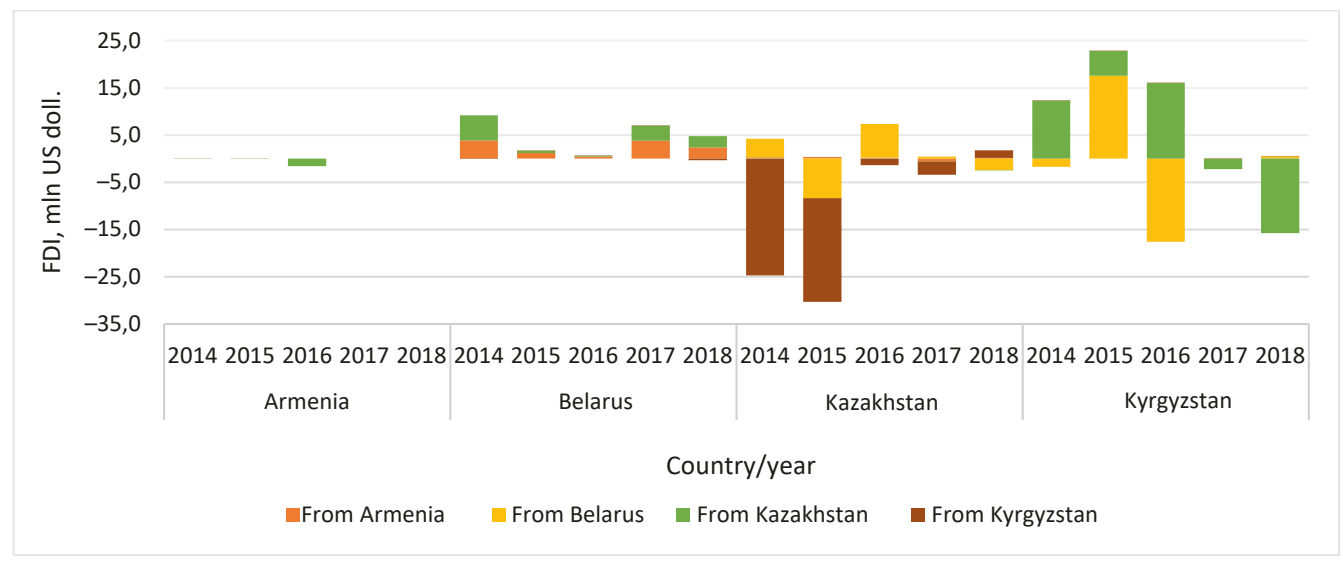

Fig. 9. Flow of foreign direct investments between Armenia, Belarus, Kazakhstan and Kyrgyzstan, 2014-2018

Based on: Euroasian Economic Commission Database. http://www.eurasiancommission.org(accessed: 12.02.2020).

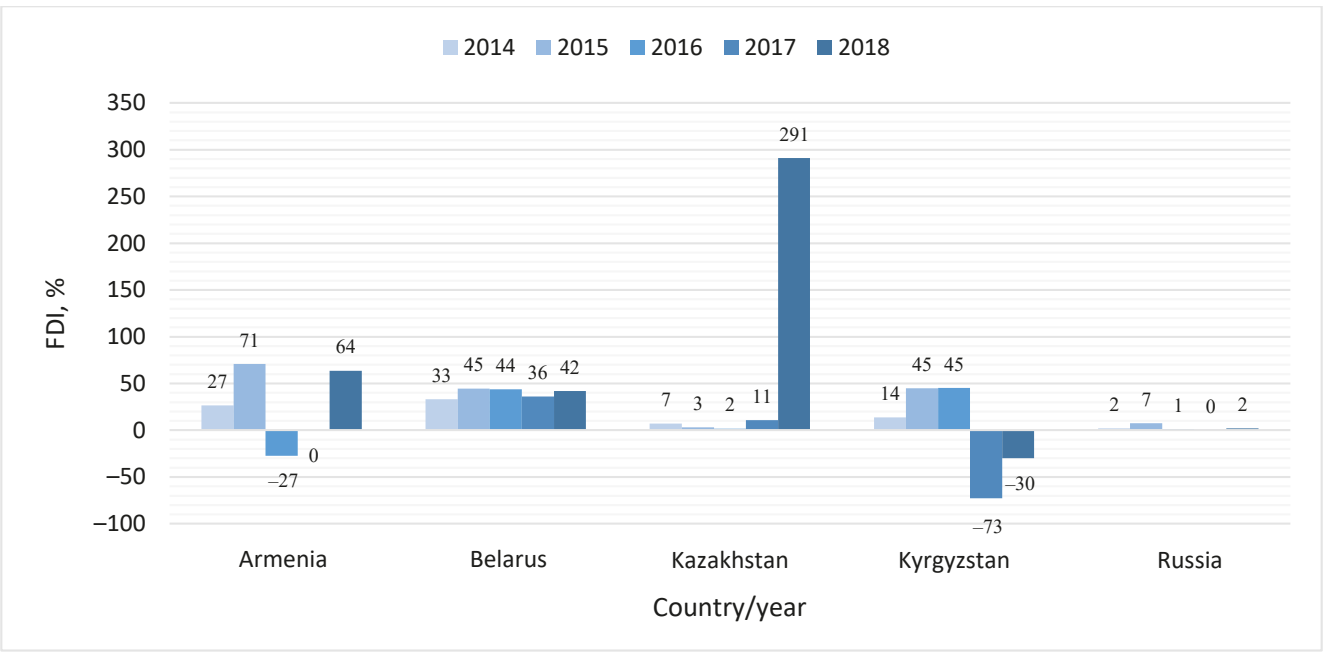

Fig. 10. The weight of foreign direct investment flows between EAEU countries in the total inflow, 2014-2018

Based on: Eurasian Economic Commission Database. URL: http://www.eurasiancommission.org(accessed: 12.02.2020).

Especially when we consider the share of direct investments between the EAEU countries in the total inflow of direct investments in those countries, it becomes obvious that these investments have a large share in the relatively small economies of the union Armenia, Kyrgyzstan, and Belarus. But for Russia and Kazakhstan, their weight is low (Fig. 10).

All of these poses an additional risk associated with exchange rate volatility in case of currency integration. 
We have also considered the convergence of the FDI inflows to EAEU countries in general. The test results show the presence of convergence at the $5 \%$ significance level for the following countries: Armenia - Kazakhstan, Armenia - Kyrgyzstan, Armenia Russia, as well as the presence of convergence at the $10 \%$ significance level for Belarus Russia and Belarus - Kyrgyzstan. As we can see, the level of convergence in the inflow of foreign direct investment within the EAEU countries is quite weak.

\subsection{Economic openness}

The openness of the economy plays an equally important role in the creation of a monetary union (Fig. 11).

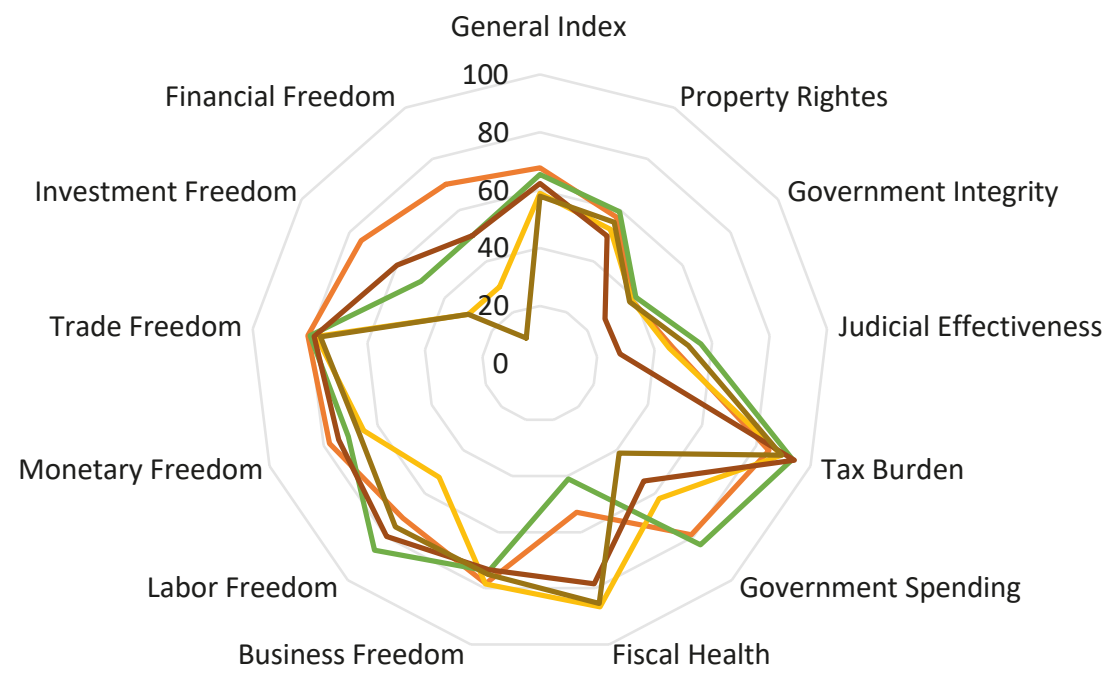

- Armenia $\longrightarrow$ Russia Kazakhstan Kyrgyzstan $\longrightarrow$ Belarus

Fig. 11. Index of economic freedom in EAEU member states, 2019

Based on: Index of economic freedom database. URL: http://www.heritage.org(accessed: 15.03.2020).

As we can see in Fig. 11, both in the general index and in most of the indicators, Armenia corresponds to a higher degree of freedom than other EAEU member states, especially in terms of investment and financial freedom. Armenia and Kazakhstan are the leaders in terms of monetary freedom. Russia, Belarus, and Kyrgyzstan are the leaders in terms of fiscal health.

\subsection{Exchange rate volatility}

Now we turn to regulatory regimes in EAEU countries and the volatility of national currencies (Figures 12, 13). 


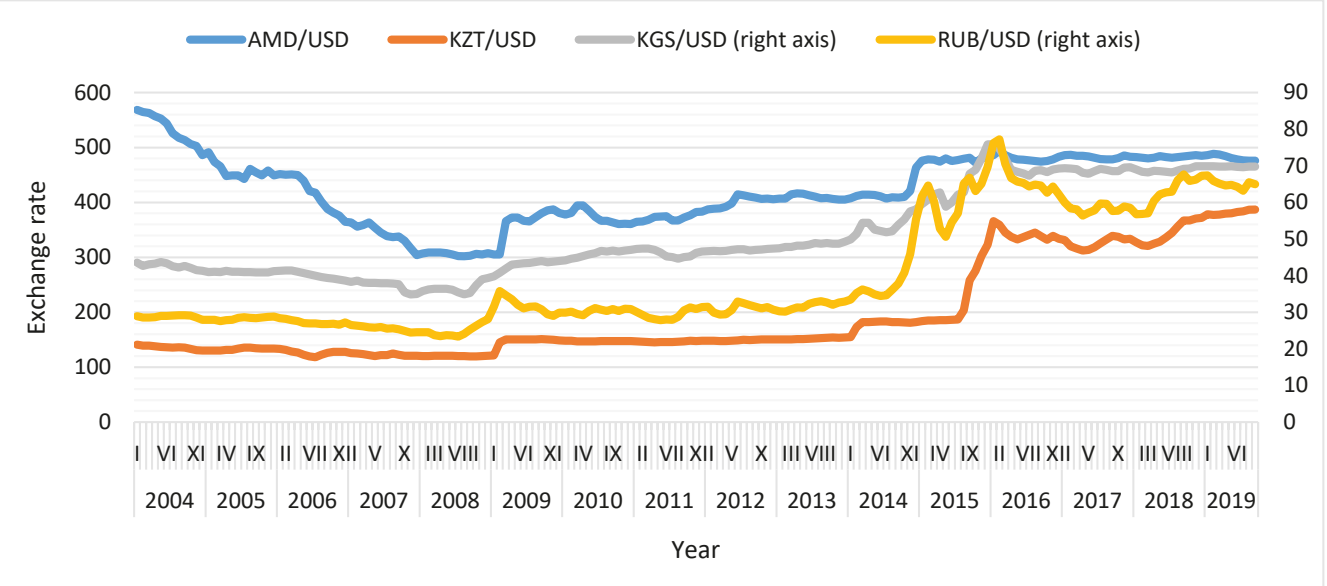

Fig. 12. The exchange rates of the national currencies of the EAEU member states (except Belarus) against the US doll., monthly, 2004-2019

Based on: Euroasian Economic Commission Database. URL: http://www.eurasiancommission.org (accessed: 12.02.2020).

The analysis of the dynamics of exchange rate fluctuations of the Russian ruble and the Armenian dram against the US dollar shows a rather tough currency regulation in both countries before the 2014-2015 currency crisis, after which Russia switched to a freefloating exchange rate regime.

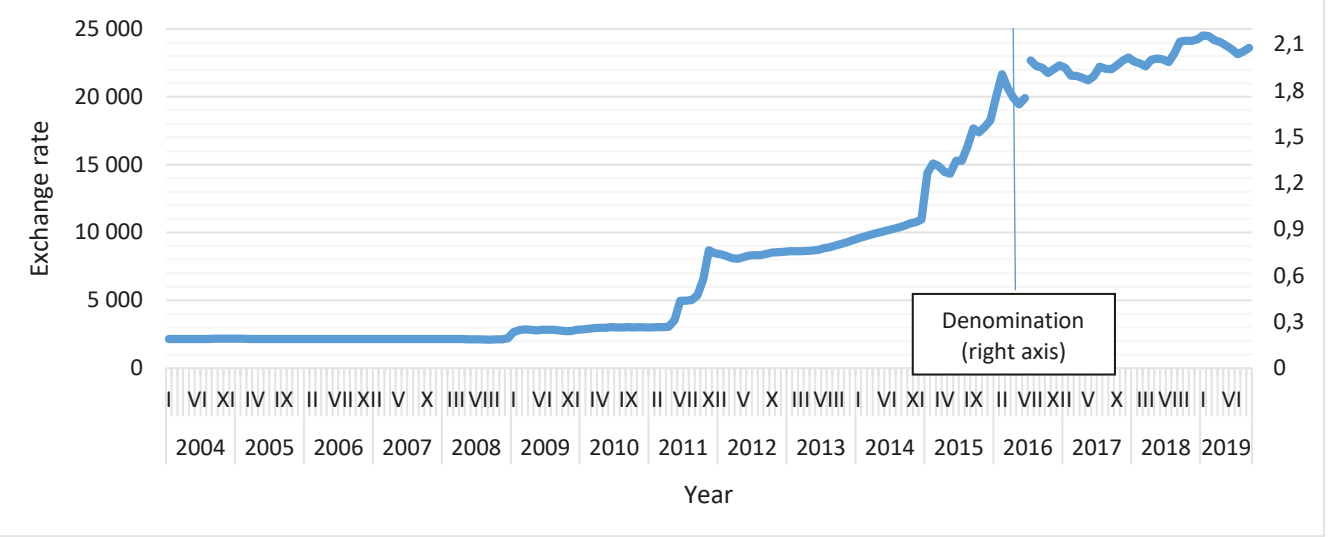

Fig. 13. The exchange rate of the Belarusian national currency against the US doll., monthly, 2004-2019

Based on: Euroasian Economic Commission Database. URL: http://www.eurasiancommission.org (accessed: 12.02.2020).

From this point of view, the observed factor is one of the most significant obstacles for currency integration between Armenia and other EAEU countries.

At the same time, the Dickey - Fuller test on the time series of exchange rates of the EAEU countries shows that at the $5 \%$ significance level, the convergence is absent 
between the Armenian dram and national currencies of all other EAEU member states. However, the results prove the existence of convergence between Russian, Belarusian, Kazakhstan's, and Kyrgyzstan's national currencies.

The standard deviation standard (SD) has been calculated as an indicator of foreign exchange rate volatility $\left(E_{i j}\right)$ [Dimitrios, Nicholas, 2014]:

$$
S D\left(E_{i j}\right)=S D\left(\ln \frac{E_{i j}^{t}}{E_{i j}^{t-1}}\right) .
$$

The higher this value, the greater the volatility of the exchange rate. Exchange rate fluctuations in the EAEU member states are quite low, especially in Armenia and Kyrgyzstan (Fig. 14).

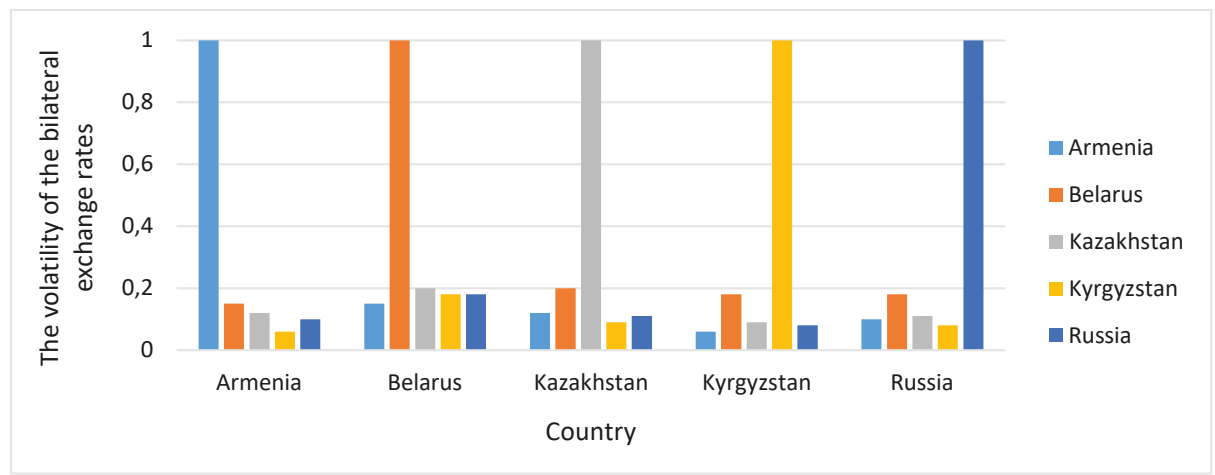

Fig. 14. The volatility of the bilateral exchange rates of the EAEU countries

Based on: Euroasian Economic Commission Database. URL: http://www.eurasiancommission.org (accessed: 08.02.2020).

\subsection{Economic diversification}

As we have seen above, the economies with a high level of diversification are more successful in creating currency unions.

Considering EAEU member states' economic structures we can say that the economies in all five countries have almost the same structure. However, in the case of Armenia and Kyrgyzstan, the agricultural sector has a relatively higher share than in other countries, and in Russia, Kazakhstan and Belarus, the industrial sector has a relatively higher share (Fig. 15). And finally, the manufacturing sector is relatively larger in Belarus.

It is known that Ogive, Entropy, and Herfindahl-Hischermann indexes are quite common as indicators of economic diversification. We have calculated the mentioned indicators for the economies of the EAEU countries.

Four segments of the economy were used to calculate the indicators: agriculture, manufacturing, services, and industry. The results of the calculations are presented below.

We have used three formulas for calculation of the indicators. The first is the Ogive index:

$$
\text { Ogive index }=\sum_{i=1}^{n} \frac{\left(s_{i}-1 / n\right)^{2}}{1 / n}
$$




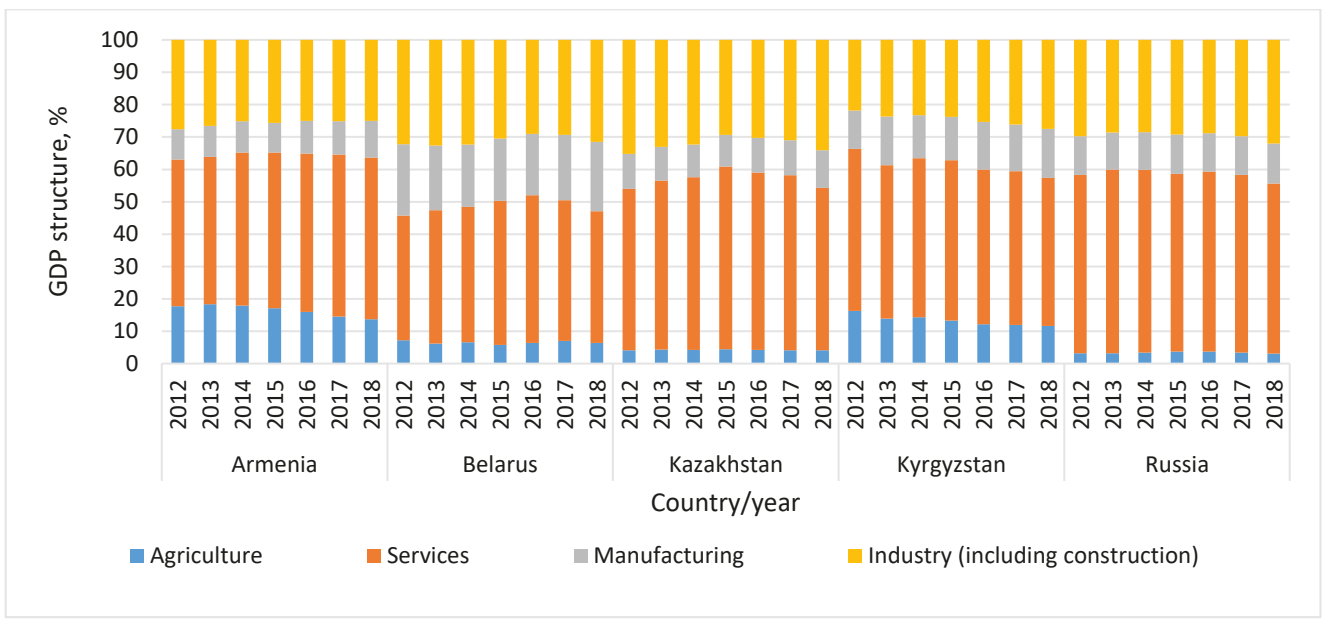

Fig. 15. GDP structure of EAEU member countries, 2012-2018

Based on: The World Bank Database. URL: https://data.worldbank.org/(accessed: 02.03.2020).

Where $S_{i}$ is the share of sector $I$ in the economic activity (GDP \%), $n$ is the number of sectors. If the index is equal to 0 , then there is a perfect diversification in the economy. The higher this value, the higher the concentration. In the case of $N$ segments, the even distribution assumes that $S_{i}$ must be equal to $1 / N$, the ideal proportion for each segment, in which case the Ogiv index will be equal to 0 , indicating the presence of an ideal diversification ${ }^{2}$.

As can be seen from Fig. 16, this index shows that the concentration level of the market in Russia and Kazakhstan is higher than in Armenia, Kyrgyzstan, and Belarus.

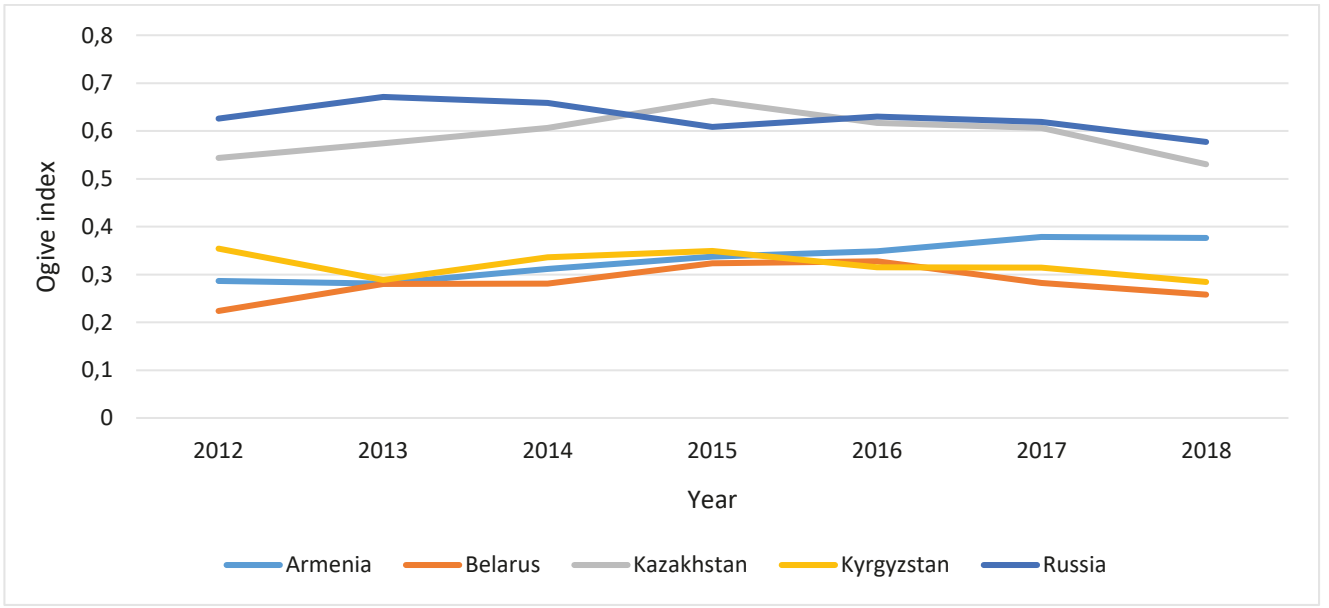

Fig. 16. Ogive index for EAEU member states, 2012-2018

Based on: The World Bank Database. URL: https://data.worldbank.org/(accessed: 12.03.2020).

2 The concept of economic diversification in the context of response measures, Technical paper by the secretariat, FCCC/TP/2016/3, p.14. URL. https://unfccc.int/sites/default/files/resource/docs/2016/tp/03. pdf (accessed: 25.10.2019). 
The second indicator is the Entropy index:

$$
\text { Entropy index }=\sum_{i=1}^{n} S_{i} \ln \frac{1}{S_{i}} .
$$

In this case, 0 corresponds to the case when the whole economy is concentrated in one sector, that is, the higher this index, the higher the economic diversification ${ }^{3}$.

As shown in Fig. 17 this index is higher in Armenia, Kyrgyzstan, and Belarus than in Russia and Kazakhstan, which again shows the relatively low level of diversification in the latter.

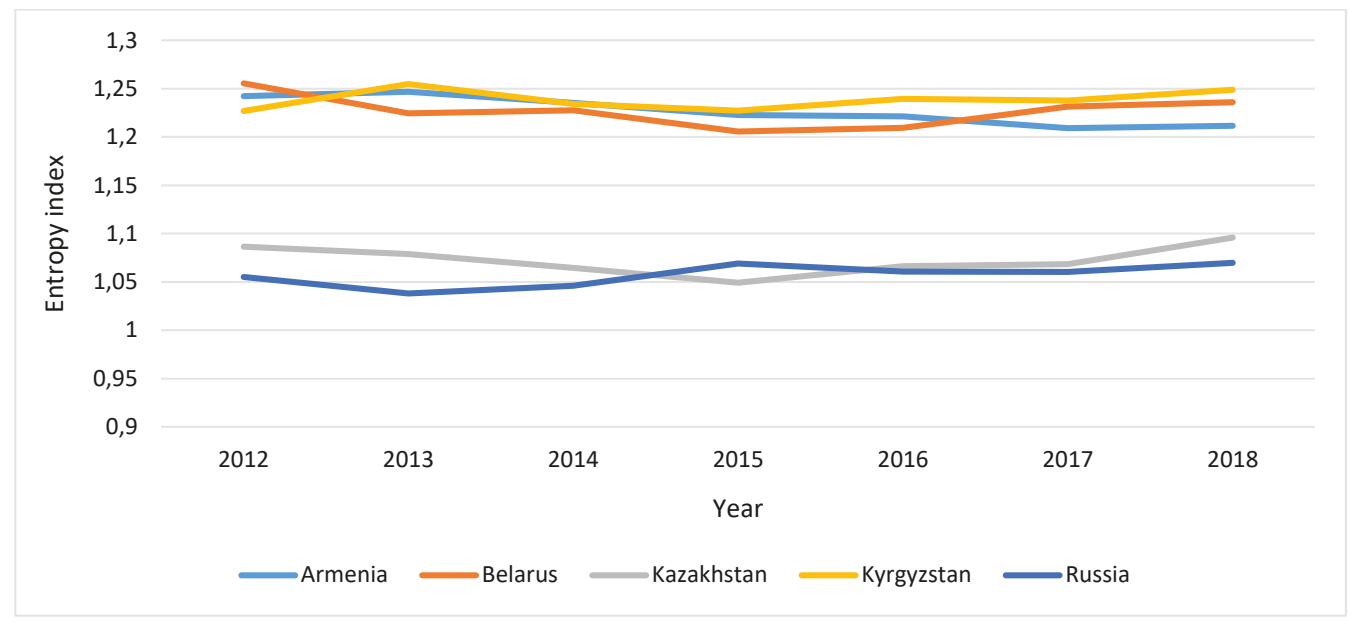

Fig. 17. Entropy index for EAEU member states, 2012-2018

Based on: The World Bank Database. https://data.worldbank.org/(accessed: 12.02.2020)

The last index is Herfindahl - Hirschmann index:

$$
\text { Herfindahl }- \text { Hirschmann index }=\sum_{i=1}^{n} S_{i}^{2} .
$$

is indicator can take values between 0 (when the weights of the sectors are equal) and 1 (when the economy is concentrated in one sector) 4 .

As we can see, all three indicators of economic diversification show that the economies of Armenia, Kyrgyzstan and Belarus are more diversified than the economies of Russia and Kazakhstan (Fig. 18).

${ }^{3}$ The concept of economic diversification in the context of response measures, Technical paper by the secretariat, FCCC/TP/2016/3, p. 14. URL.https://unfccc.int/sites/default/files/resource/docs/2016/tp/03.pdf (accessed: 25.10.2019).

${ }^{4}$ The concept of economic diversification in the context of response measures, Technical paper by the secretariat, FCCC/TP/2016/3, p.13. URL: https://unctad.org/system/files/official-document/ditc-ted03102017-Trade-Measures-UNFCC-NatDet.pdf (accessed: 06.01.2020) 


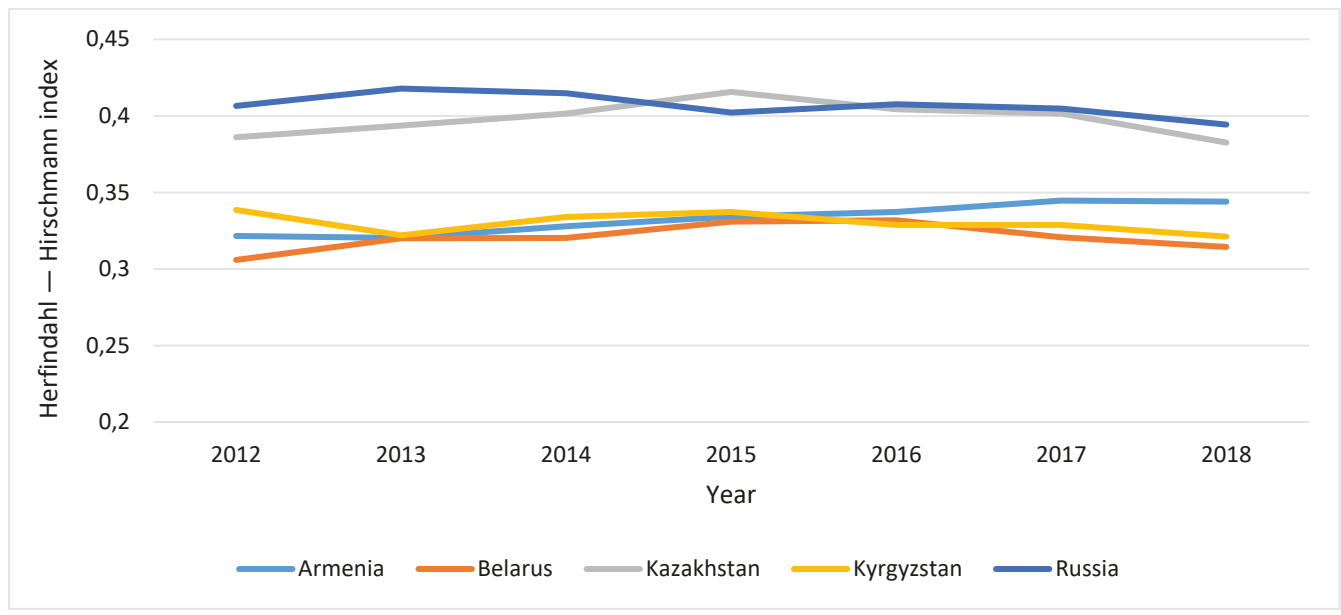

Fig. 18. Herfindahl-Hirschmann index for EAEU member states, 2012-2018

Based on: The World Bank Database. URL: https://data.worldbank.org/(accessed: 02.01.2020).

\subsection{Real shocks}

To analyze the asymmetry of real shocks, it is necessary to take into account not only their mutual correlation but also the difference between absolute values. We used the Pearson Correlation Index for real GDP growth logarithms to estimate the correlation of real shocks (fig. 19).

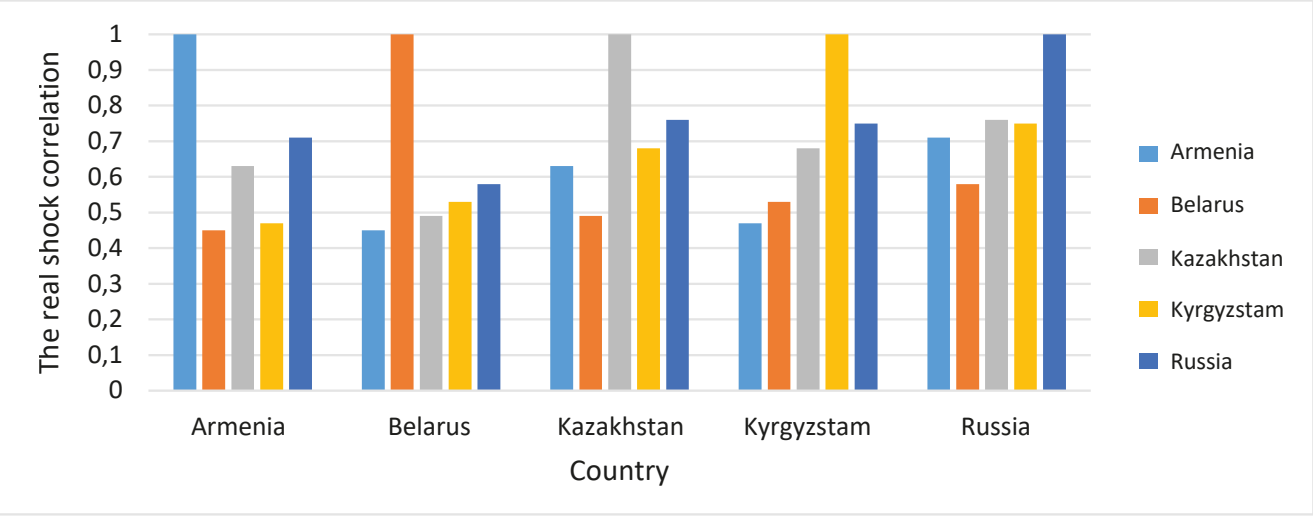

Fig. 19. The real shock correlation in the EAEU member states

Based on: The World Bank Database. URL: https://data.worldbank.org/(accessed: 02.01.2020).

The high rate of correlation between two countries may indicate that their economies are affected by symmetrical shocks, which leads to a change in real economic activity in the same direction. Thus, the stabilization of the economies of the member states of the union will require similar measures of economic policy. The results show that there is a correlation between the following country pairs: Armenia - Russia, Kazakhstan - Rus- 
sia, Kazakhstan - Kyrgyzstan, Kyrgyzstan - Russia. The only economy where real shocks are not correlated at least with one of the member states of the union is Belarus.

The difference between the standard deviations of the real GDP growth rates and the real GDP growth rate was used as an indicator of the volatility of real shocks [Blaise, Aaron, 2013]:

$$
S D\left(Y_{i j}\right)=\left|S D\left(\ln \frac{R G D P_{i}^{t}}{R G D P_{i}^{t-1}}\right)-S D\left(\ln \frac{R G D P_{j}^{t}}{R G D P_{j}^{t-1}}\right)\right| .
$$

The main hypothesis is as follows: if the correlation coefficient is low and the volatility index is high, then real shocks are asymmetric.

The volatility of real shocks is low in all pairs of EAEU member states. Thus, it can be concluded that real shocks are symmetrical for all EAEU countries except Belarus, in which case the level of correlation was low (Fig. 20).

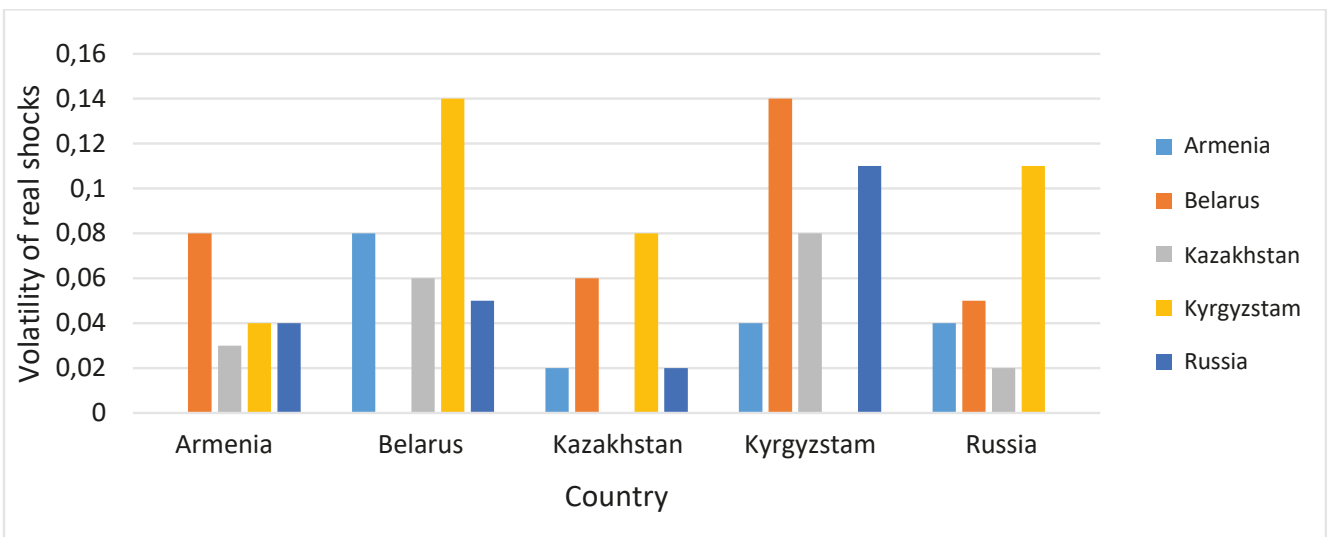

Fig. 20. Volatility of real shocks in the EAEU countries

Based on: The World Bank Database. URL: https://data.worldbank.org/ (accessed: 03.02.2020).

\subsection{Monetary shocks}

Following the example of calculations done for real shocks, we used the correlation coefficients of the growth rate of money supply, as well as the values of their standard deviation differences to describe the asymmetry of monetary shocks:

$$
S D\left(Y_{i j}\right)=\left|S D\left(\ln \frac{M_{i}^{t}}{M_{i}^{t-1}}\right)-S D\left(\ln \frac{M_{j}^{t}}{M_{j}^{t-1}}\right)\right| .
$$

The Figures 21 and 22 show that although monetary shocks are not volatile within the EAEU member states, they are not correlated as well. This means that we do not have good enough grounds to reject the main hypothesis. Monetary shocks are asymmetric. 


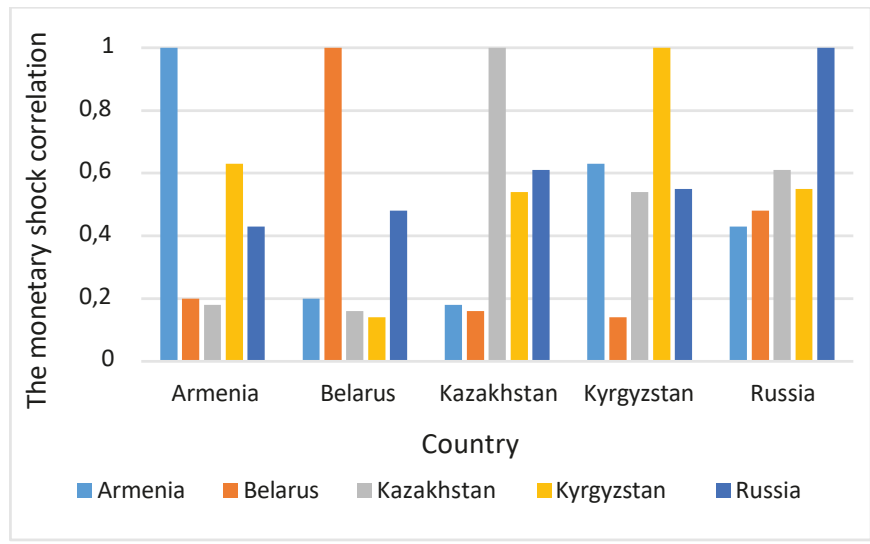
states

Fig. 21. The monetary shock correlation in the EAEU member

Based on: The World Bank Database. URL: https://data.worldbank.org/ (accessed: 02.02.2020).

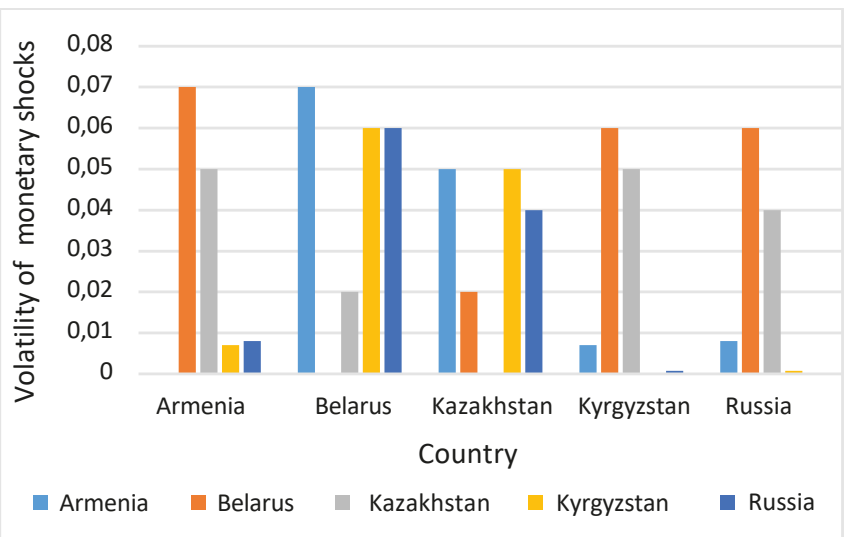

Fig. 22. Volatility of monetary shocks in the EAEU countries

Based on: The World Bank Database. URL: https://data.worldbank.org/ (accessed: 02.02.2020).

\subsection{The level of volatility of inflation}

One of the key indicators for the creation of this or that type of currency integration is the price level. The comparison of price levels in EAEU countries shows that it is quite different both in terms of price levels and inflation (Fig. 23).

The Dickey - Fuller's test, applied to the EAEU countries CPI data of 1996-2017, showed the existence of convergence between Armenia, Kyrgyzstan, and Kazakhstan at a $5 \%$ significance level, as well as Russia and Armenia at a $10 \%$ level. However, there is no convergence for the level of inflation in Belarus, as well as in Russia and other EAEU members except Armenia. 


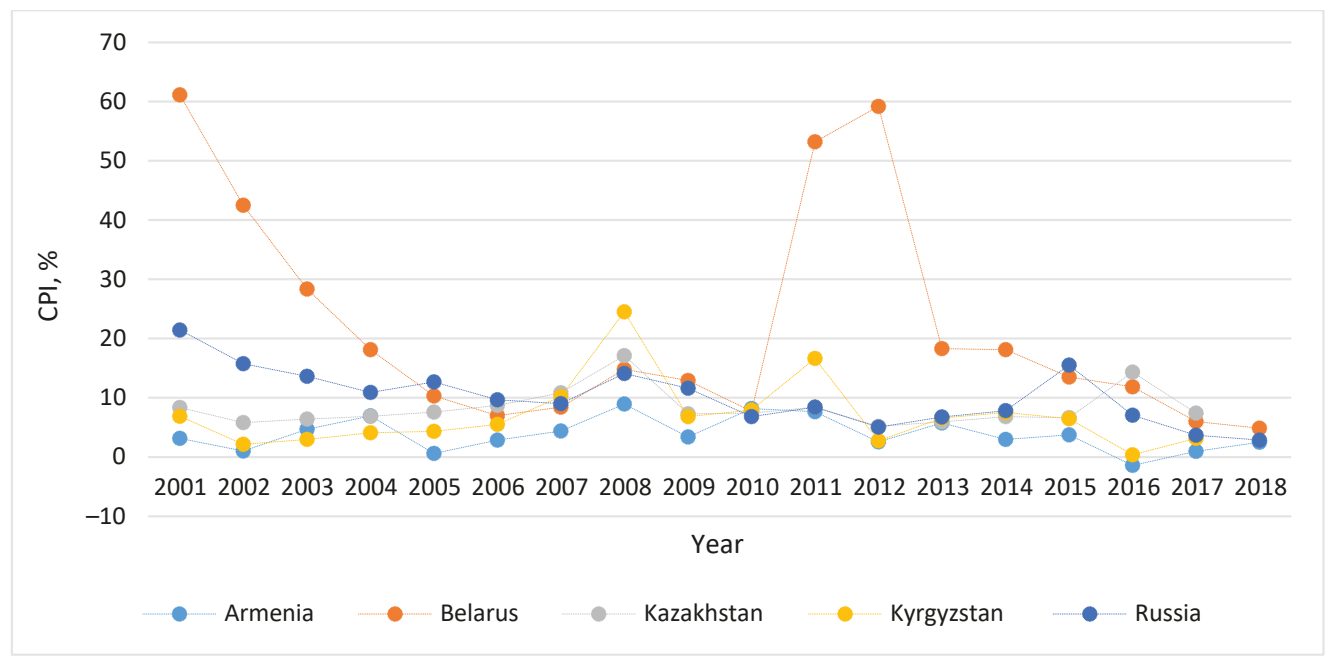

Fig. 23. Inflation, consumer prices, annually, 2001-2018

Based on: The World Bank Database. URL: https://data.worldbank.org/ (accessed: 03.03.2020).

Analyzing the similarity of inflationary processes was carried out using the methodology of calculations described above for real and monetary shocks:

$$
S D\left(Y_{i j}\right)=\left|S D\left(\ln \frac{C P I_{i}^{t}}{C P I_{i}^{t-1}}\right)-S D\left(\ln \frac{C P I_{j}^{t}}{C P I_{j}^{t-1}}\right)\right| .
$$

According to the theory, in the case of inflation rates, as well as in the case of a significant difference in their comparative dynamics, comparative price fluctuations are possible in pairs of observed countries. The floating exchange rate policy can absorb the consequences of such fluctuations, so the loss of the flexibility of the monetary policy can increase the costs of currency integration.

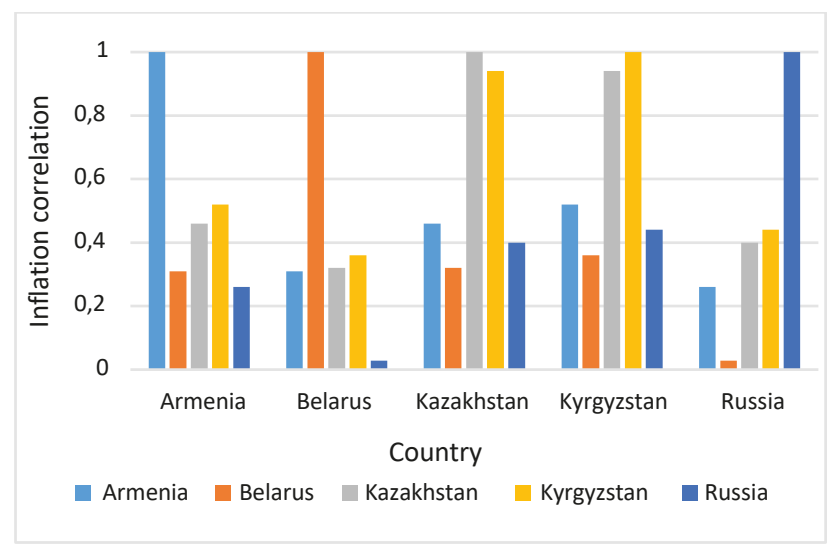

Fig. 24. Inflation correlation within the EAEU

Based on: The World Bank Database. URL: https://data.worldbank.org/ (accessed: 01.02.2020). 
As shown in Figures 24 and 25, volatility is low for all member states except Belarus, and among inflationary trends, the correlation is quite low between Belarus and Russia, and average between Armenia, Kazakhstan, and Kyrgyzstan. It is significantly higher only between Kazakhstan and Kyrgyzstan. Thus, inflationary processes among the EAEU countries generally are not symmetrical.

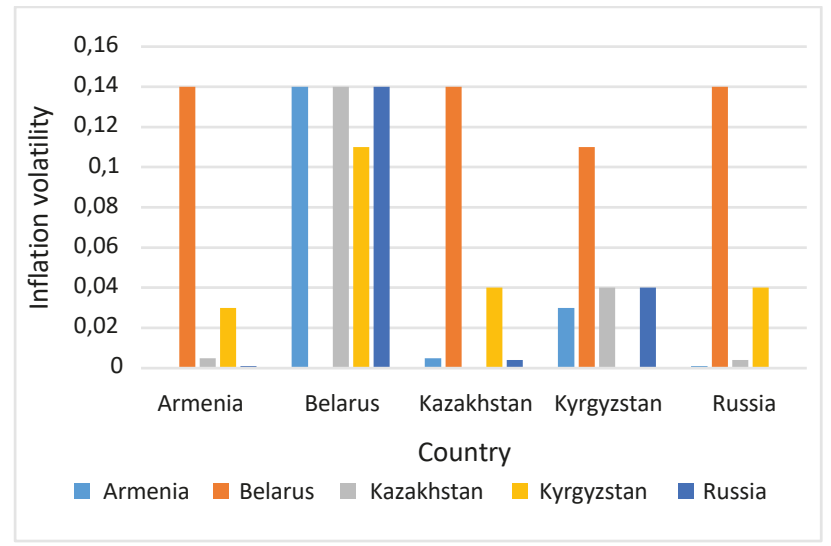

Fig. 25. Inflation volatility within the EAEU

Based on: The World Bank Database. URL: https://data.worldbank. org/ (accessed: 01.02.2020).

\subsection{Mutual trade}

To describe mutual trade between the EAEU member states, we have calculated the share of foreign trade $\left(E x_{i j}, I m_{i j}\right)$ in the nominal GDP of the national economy $\left(\operatorname{NGDP}_{i}\right)$ :

$$
T R_{i j}=\text { Average }_{t}\left(\frac{E x_{i j}^{t}+I m_{j i}^{t}}{N G D P_{i}^{t}}\right) .
$$

In general, one of the main claims of the OCZ theory in favor of currency integration is the volume of mutual trade between member states. As we can see, from Fig. 26, all member states have active trade relations with Russia, but trade between other country pairs are almost non-existent.

\subsection{The size of the economy}

The smaller the economy, the greater its benefits from currency integration. The size of the economy is determined as follows:

$$
\text { Size }_{i j}=\text { Average }_{t}\left(\frac{R G D P_{i}^{t}}{R G D P_{j}^{t}}\right) .
$$

Thus, Russia's economy is much larger than the economies of other member states of the union, with Armenia and Kyrgyzstan having the smallest economies (respectively 144 and 264 times smaller than the Russian economy) (Fig. 27). 


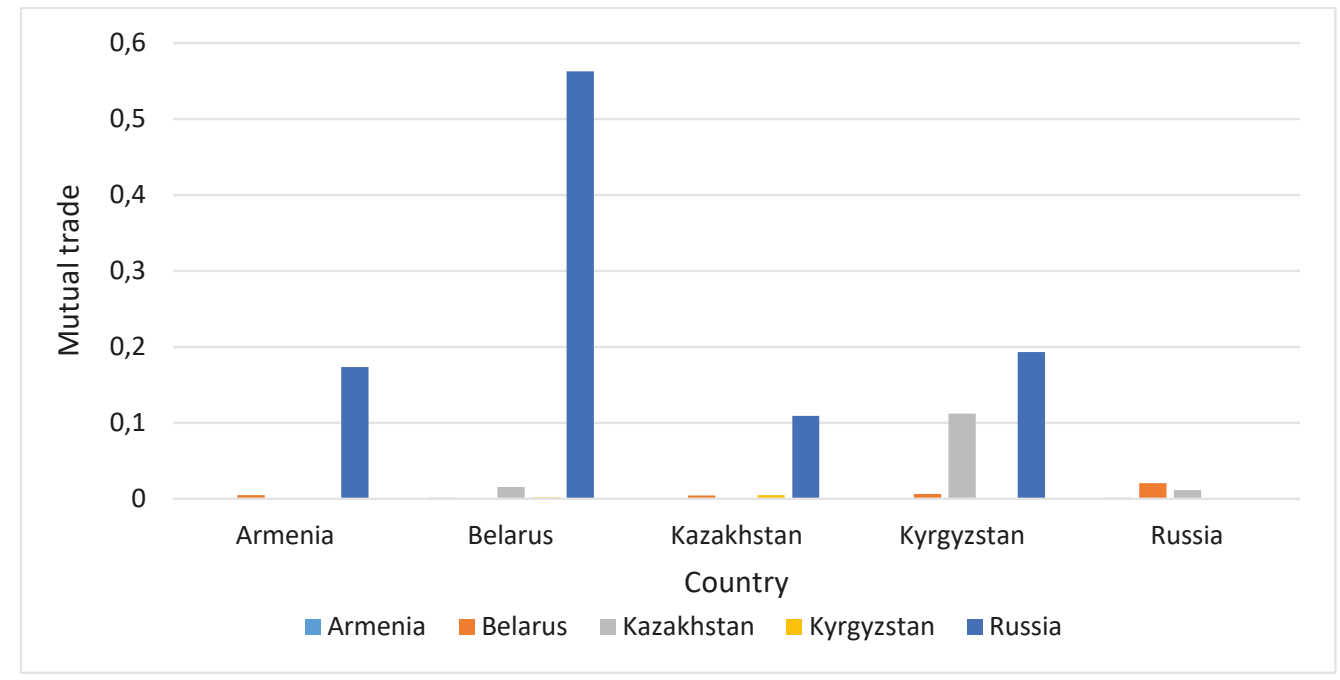

Fig. 26. Mutual trade between the EAEU member states

Based on: Euroasian Economic Commission Database. URL: http://www.eurasiancommission.org (accessed: 01.02.2020).

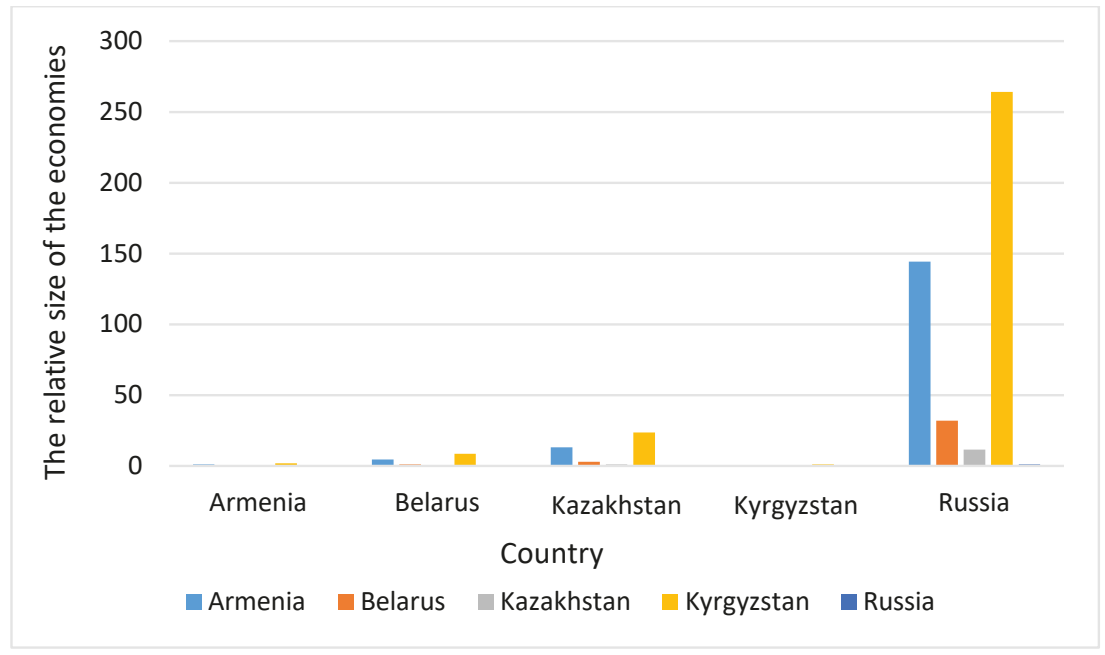

Fig. 27. The relative size of the economies of the EAEU member states

Based on: Euroasian Economic Commission Database. URL: http://www.eurasiancommission. org (accessed: 12.10.2019).

Taking into account all circumstances, EAEU member states do not meet certain requirements for mutually beneficial currency integration. Although according to some indicators EAEU countries are ready for possible monetary and currency integration, in practice this is hindered by several factors, such as high levels of dollarization, underdeveloped financial sectors, shadow economies, dependence on foreign remittances, weak economic diversity, dependence on foreign price shocks, and other issues raised here. In 
such a situation, the introduction of a single monetary policy could lead to a deeper recession in the post-crisis period.

\section{Conclusion}

In the context of joining the EAEU, the economies of countries in the Eurasian economic space are subject to greater mutual influence. Moreover, all these countries are united by a high dependence on exchange rate volatility. However, when considering the monetary policies of the EAEU countries, it is striking that there is no harmonization of currency regulation by central banks, which brings negative consequences for all the economies of the EAEU, and for Armenia in particular.

As part of this study, we carried out an analysis of currency integration within the EAEU and considered the main issues and prospects of integration in the Eurasian space. The study of integration processes in the Eurasian space makes it possible to highlight a list of general factors that must be taken into account when developing currency integration processes between different regions. We highlight the following: the sequence of integration processes, with the identification of priority issues that need to be solved at each stage of development; the importance of establishing effective payment and settlement mechanisms; the need for an "integration core" that will stimulate deeper integration; the presence of economic and political decisions, as well as a clear focus on integration; the importance of converging legislation; and liberalization of the approach to arkets of member countries of the economic and monetary union and a relatively equal level of economic development.

In this context, the macroeconomic balance of the economies of the EAEU member countries is characterized by the presence of many institutional issues that could become a significant obstacle to creating a single currency zone. Following the example of the EU, a high level of government debt and budget deficits in EAEU countries can increase risks associated with creating a currency integration union.

The criteria for the countries' compliance with the potential creation of a single currency zone, considered in the paper, substantiated the inexpediency of creating a currency union at this stage. Also, the authors proposed additional criteria that take into account the specifics of developing economies.

\section{References}

Aghion P., Bacchetta P., Ranciere R., Rogoff K. (2006) Exchange rate volatility and productivity growth: The role of financial development. NBER Working Paper, no. 12117, p. 48.

Alesina A., Barro R., Tenreyro S. (2002) Optimal Currency Areas. NBER Working Paper, no. 9072, p. 49.

Aristotelous K., Fountas S. (2012) What is the Impact of Currency Unions on FDI Flows? Evidence from Eurozone Countries. South-Eastern Europe Journal of Economics, vol. 2, pp. 87-98.

Bergin P.R., Lin Ch. Y. (2010) The dynamic effects of currency union on trade. Coventry: Department of Economics, University of Warwick. CAGE Online Working Paper Series, vol. 2010, no. 11, p. 46.

Bertolla G.(1989) Factor Flexibility, Uncertainty and Exchange Rate Regimes. A European Central Bank, pp. $95-119$

Blaise G., Aaron M. (2013) The exchange rate, real economy and financial markets. BIS Papers, no.73, pp. 11-23.

Canofari P., Marini G., Piersanti G. (2012) The sustainability of monetary unions. Can the Euro survive? CEIS Working Paper, no. 226, p. 11. 
Cheung Y.W., Pascual A.G. (2004) Testing for output convergence: a re-examination. Oxford Economic Papers, no. 56, pp. 45-63.

Corden W. (1973). The Adjustment Problem. European Monetary Unification and Its Meaning for the United States. Eds L. B. Krause and W. S. Salant. Washington, The Brookings Institution., pp. 159-184.

De Grauwe P. (2003) Economics of monetary union. $5^{\text {th }}$ ed. Oxford University Press, Oxford, UK. 258 p.

De Grauwe P. (2006) On monetary and political union. CESifo Forum, no. 4, pp. 3-10.

Dimitrios S., Nicholas T. (2014) Exchange Rate Volatility and Aggregate Exports: Evidence from Two Small Countries. Hindawi Publishing Corporation, ISRN Economics, pp. 1-10.

Edwards S., Magendzo I. (2006) Strict Dollarization and Economic Performance: An Empirical Investigation. Journal of Money, Credit and Banking, vol.38, pp. 269-282. https://doi.org/10.1353/mcb.2006.0016.

Fleming J. (1971) On Exchange Rate Unification. Economic Journal, no. 81, pp. 467-488.

Frankel J., Rose A. (1998) The Endogeneity of the Optimum Currency Area Criteria. The Economic Journal, vol. 108, no. 449, pp. 1009-1025.

Fukuda H. (2002) The theory of Optimum Currency Areas. Keio University, pp. 1-17.

Ingram J.C. (1969) Comment: The Currency Area Problem. Monetary Problems of The International Economy. Ed. Robert A. Mundell and Alexander L. Swoboda. The University of Chicago Press, Chicago, pp. $95-100$.

Kenen P. (1969) The Theory of Optimum Currency Areas: An Eclectic View. Monetary Problems of the International Economy. Ed. Mundell R. and Swoboda. The University of Chicago Press, Chicago, pp. 41-60.

Krugman P. (1991) Target Zones and Exchange Rate Dynamics. The Quarterly Journal of Economics, vol. 106, no. 3, pp. 669-682.

Krugman P., Obstfeld M. (2003) International Economics: Theory and Policy. Addison Wesley. 754 p.

Lipinska A., Thadden L. (2012) On the (In)Effectiveness of Fiscal Devaluations in a Monetary Union. SSRN Electronic Journal, pp. 1-46. https://doi.org/10.2139/ssrn.2195201.

McKinnon R. (1963) Optimum Currency Areas. American Economic Review, no. 53, pp.717-725.

Mundell R. (1961) A Theory of Optimal Currency Areas. American Economic Review, no. 51, pp. 657-665.

Rose A. (2000) One money, one market: Estimating the effect of common currencies on trade. Economic Policy, no. 30, pp. 9-45.

Rose A. (2008) Is EMU becoming an optimum currency area? The evidence on trade and business cycle synchronization. Haas School of Business. University of California, Berkeley, pp. 1-16.

Rose A., Engel Ch. (2002) Currency unions and international integration. Journal of Money, Credit, and Banking, vol. 34, no.4, pp. 1067-1089.

Rose A., Stanley T. (2005) A meta-analysis of the effect of common currencies on International Trade. Journal of Economic Surveys, no. 19, pp. 347-365.

Schnabl G. (2009) Exchange rate volatility and growth in emerging Europe and East Asia. Open Economies Review, vol.20, no. 4, pp.565-587.

Vaubel R. (1976) Real Exchange Rate Changes in the European Community: The Empirical Evidence and Its Implications for European Currency Unification. Weltwirtshaftliches Archive, no. 112, pp.429-470.

Received: 21.04 .2020

Accepted: 28.12 .2020

Authors' information:

Mariam A. Voskanyan - Dr. Sci. in Economics, Associate Professor; mariam.voskanyan@rau.am Ani H. Galstyan - PhD in Economics, Senior Lecturer; ani.galstyan@rau.am 


\title{
Валютное регулирование в экономических союзах: на примере Евразийского экономического союза
}

\author{
М. А. Восканян, А. Г. Галстян \\ Российско-Армянский (Славянский) университет, \\ Армения, 0051, Ереван, ул. Овсепа Эмина, 123
}

Для цитирования: Voskanyan M.A., Galstyan A.H. (2021) Exchange rate regulation in economic unions: The case of Euroasian Economic Union. Вестник Санкт-Петербургского университета. Экономика. Т.37. Вып. 1. С. 140-165. https://doi.org/10.21638/spbu05.2021.106

Статья посвящена рассмотрению анализа валютного регулирования в странах ЕАЭС с позиции гармонизации валютных политик в условиях экономической интеграции. Объектом исследования выступает валютное регулирование в странах евразийской интеграции. Основная гипотеза исследования заключается в том, что в настоящее время страны - участницы ЕАЭС не готовы к созданию валютной интеграции, что обусловлено наличием в экономиках множества искажений макроэкономического характера. В работе предпринимается попытка оценить возможность создания валютного союза посредством анализа и оценки ключевых критериев создания валютных интераций, известных в научной литературе. С этой целью приводится литературный обзор ключевых предпосылок валютной интеграции, в том числе с учетом имеющего опыта в странах еврозоны. Затем представлен анализ валютного регулирования в странах ЕАЭС с точки зрения соотвествия ключевым критериям валютной интеграции и дается оценка ключевых факторов валютной интеграции. Теоретической и методологической базой исследования являются классические и современные подходы в области денежно-кредитного и валютного регулирования. В частности, за основу были взяты изыскания современных аналитиков МВФ, крупнейших Центральных банков мира, известных специалистов в области монетарной политики. Результаты исследования показали нецелесообразность создания в настоящее время валютного союза в рамках евразийского экономического пространства.

Ключевые слова: экономическая интеграция, валютный союз, валютное регулирование, EАЭС.

Контактная информация:

Восканян Мариам Амбариумовна - д-р экон. наук, доц.; mariam.voskanyan@rau.am Галстян Ани Гамлетовна - канд. экон. наук, ст. преп.; ani.galstyan@rau.am 